\title{
CATALYTIC POTENTIAL OF SOIL HYDROLASES IN NORTHEAST CHINA UNDER DIFFERENT SOIL MOISTURE CONDITIONS
}

\author{
Y.L. Zhang ${ }^{1,2,4}$, Cc.X. Sun ${ }^{3}$, L.J. Chen ${ }^{1 *}$ and Z.H. Duan ${ }^{2}$ \\ ${ }^{1}$ Department of Soil and Plant Nutrition, Institute of Applied Ecology, Chinese Academy of \\ Sciences, P. O. Box 417, 110016 Shenyang, People's Republic of China. ${ }^{2}$ Cold and Arid Regions \\ Environment and Engineering Research Institute, Chinese Academy of Sciences. ${ }^{3}$ Institute of \\ Biotechnology, Northeastern University, Shenyang 110004, People's Republic of China. \\ ${ }^{4}$ Key Laboratory of Terrestrial Ecological Process, Institute of Applied Ecology, Chinese \\ Academy of Sciences, Shenyang 110016, People's Republic of China. \\ *Corresponding author: yulanenzymes@yahoo.com.cn
}

\begin{abstract}
An incubation test with black soil (Phaeozem), Albic soil (Albic Luvisols), brown soil (Cambisols), and cinnamon soil (Chromic Luvisol) from Northeast China was conducted under the conditions of $10 \%, 20 \%$ and $30 \%$ field capacity, and the kinetic parameters of soil urease, phosphatase, and arylsulphatase were determined, aimed to study the changes in the catalytic potential of these enzymes under different soil moisture conditions. All test enzymes exhibited typical Michaelis-Menten kinetic behaviors. The test enzymes exhibited the highest enzyme-substrate affinity $\left(1 / K_{\mathrm{m}}\right)$ at $20 \%$ or $30 \%$ field capacity. With increasing soil moisture content, the $V_{\max }$ of test soil urease decreased, while that of soil phosphatase and arylsulphatase increased, with the maximum $V_{\max } / K_{\mathrm{m}}$ of urease at $20 \%$ field capacity and that of phosphatases and arylsulphatase at $30 \%$ field capacity. To control soil moisture condition could be a feasible way in regulating the biochemical transformation processes of soil nutrients catalyzed by soil hydrolases.
\end{abstract}

Keywords: Soil enzymatic kinetic parameters, soil hydrolase, soil moisture condition

\section{INTRODUCTION}

Soil hydrolases are a group of soil enzymes responsible for the catalytic hydrolysis of soil substances (Tabatabai and Bremner, 1971, 1972; Dick and Tabatabai, 1993; Asmar et al., 1994; Amador et al., 1997), among which, urease, phosphatase, and arylsulphatase catalyze the hydrolysis of soil amide $\mathrm{N}$, organic $\mathrm{P}$, and organic $\mathrm{S}$, respectively, being of significance in the N,P, and S uptake by plants (Burns, 1978; Sarapatka and Krskova, 1997). Soil moisture regime had definite effects on the catalytic potential of soil enzymes (Ross, 1987; García et al., 2002; Sardans and Penuelas, 2005). Engasser and Horvath (1976) reported that soil moisture content affects the movement of enzymes and their 
substrates in soil, while the diffusion limitation of the substrates may directly affect soil enzyme $K_{m}$. Some researches (Burns, 1978; Ladd, 1985; Boyd and Mortland, 1990; Sardans and Penuelas, 2005) also showed that the changes in soil moisture content had significant effects on the kinetic parameters of soil hydrolases. Therefore, to measure the kinetic parameters of soil hydrolases under different soil moisture conditions will help to the understanding of the changes in the substrate affinity and the catalytic activity of soil hydrolases, and further, help to adopt appropriate measures to regulate soil moisture regime to maintain optimal hydrolase activities.

In this paper, black, albic, brown, and cinnamon soil, the main agricultural soils in Northeast China, were sampled, and an incubation test was conducted to study the catalytic potential of urease, phosphatase, and arylsulphatase as affected by different soil moisture conditions, aimed to approach the appropriate soil moisture regime for these enzymes.

\section{MATERIALS AND METHODS}

\section{Soil samples collection and preparation}

Four sampling sites were installed (Table $1)$, and $0-20 \mathrm{~cm}$ soil samples over an approximately 1 ha at each site were collected in early spring before sowing.

In all cases, 50 - 60 subsamples collected were combined into a composite sample, transported to laboratory in isothermal bags, and passed through 2 $\mathrm{mm}$ sieve after removing roots and plant debris. Parts of the subsamples (1000 g, $\mathrm{n}=3$ ) of each composite sample were preincubated at ca. $60 \% \mathrm{WHC}$ and $25^{\circ} \mathrm{C}$ for $14 \mathrm{~d}$ to stabilize the biological and biochemical characteristics before treatment, and the other parts were airdried and $2 \mathrm{~mm}$ sieved for chemical and physical properties analysis. Some chemical and physical properties of test soils were shown in Table 2 .

\section{Incubation test}

After pre-incubation, the prepared soil samples were aerobically incubated at room temperature for $14 \mathrm{~d}$. Three treatments with triplicates were installed, i.e., $10 \%, 20 \%$ and $30 \%$ field capacity to simulate minimal, normal, and maximum soil humidity, respectively. Distilled water was added daily to compensate the water loss from incubation.

\section{Soil chemical properties analysis}

Soil moisture content was determined gravimetrically after oven-dried at $105^{\circ} \mathrm{C}$, soil $\mathrm{pH}$ was determined by glass electrode (soil:water ratio, 1:2.5), soil total organic carbon and total nitrogen $(\mathrm{N})$ were determined by CNS analyzer Elementar Vario EL III (Matejovic, 1995), soil total phosphorus was determined by UV Spectrophotometer (Carry 50, Varian, American) after digest, soil total sulphur (S) was determined by the turbidimetric method after magnesium nitrate oxidation (Fox, 1987), Alkali-hydrolyzed $\mathrm{N}$ was determined by boracic acid absorbing $\mathrm{NH}_{3}$ released by $\mathrm{NaOH}$., soil available phosphorous (P) extractable with $\mathrm{NaHCO}_{3}$ was determined by Olsen method (Kuo, 1996), and soil available sulfur was determined by the turbidimetric method after acetate and phosphate extraction (Fox, 1987). Particle size distribution was determined by Robinson pipette method and with Calgon as dispersant. These methods are described by $\mathrm{Lu}$ (2000). 
Catalytic potential of soil hydrolases in Northeast China, Zhang et al.

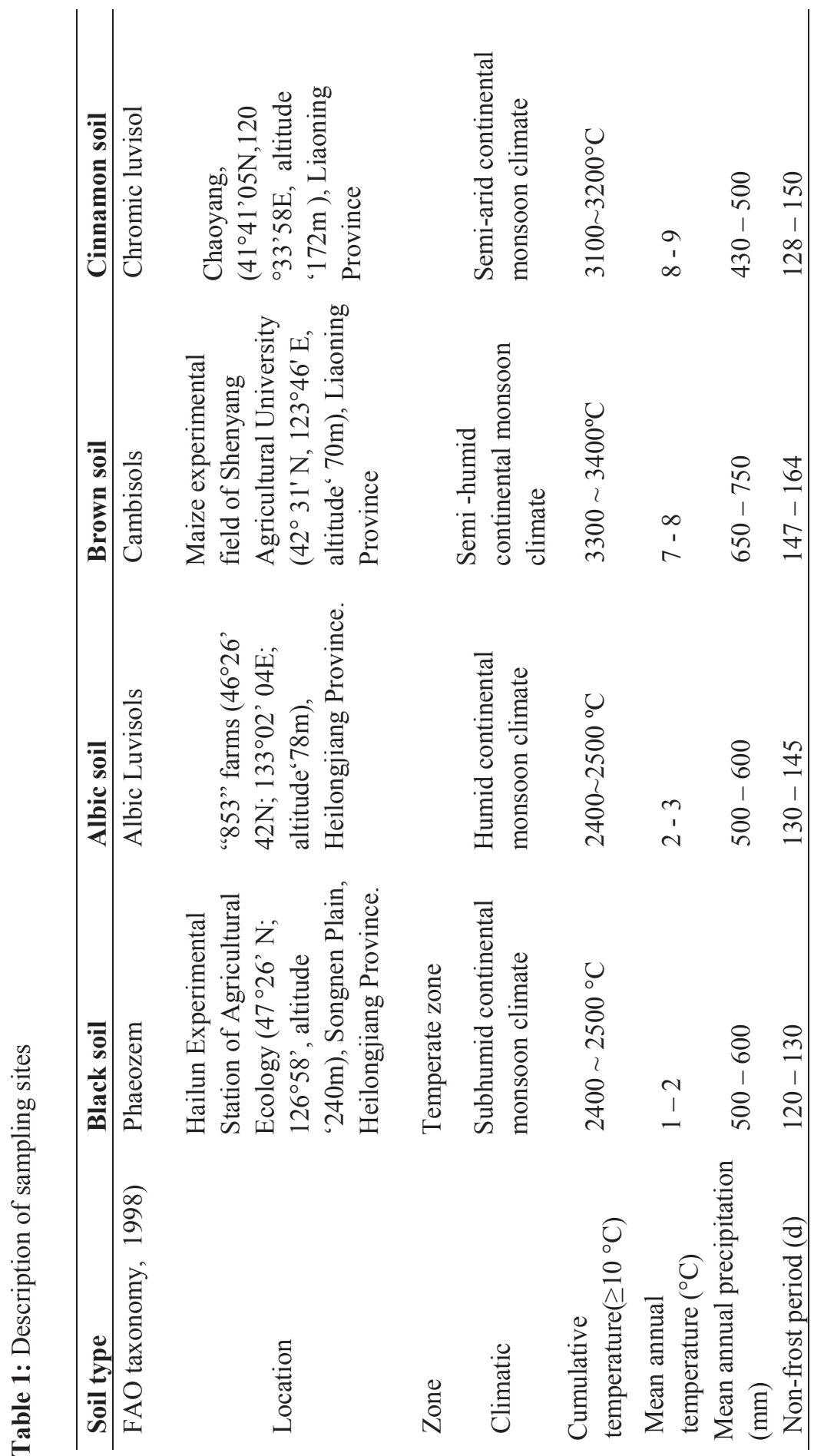


Table 2: Soil properties

\begin{tabular}{|c|c|c|c|c|}
\hline & Black Soil & Albic Soil & Brown Soil & Cinnamon Soil \\
\hline $\mathrm{pH}\left(\mathrm{H}_{2} \mathrm{O}, 1: 2.5\right)$ & $5.54 \mathrm{a}$ & $5.81 \mathrm{~b}$ & $5.46 \mathrm{a}$ & $8.21 \mathrm{c}$ \\
\hline $\begin{array}{l}\text { Organic matter } \\
\left(\mathrm{g} \mathrm{kg}^{-1}\right)\end{array}$ & $46.84 \mathrm{~d}$ & $32.96 \mathrm{c}$ & $14.47 \mathrm{~b}$ & $10.54 \mathrm{a}$ \\
\hline Total N $\left(\mathrm{g} \mathrm{kg}^{-1}\right)$ & $2.22 \mathrm{c}$ & $1.93 \mathrm{~b}$ & $0.97 \mathrm{a}$ & $0.93 \mathrm{a}$ \\
\hline Total P $\left(\mathrm{g} \mathrm{kg}^{-1}\right)$ & $0.79 \mathrm{c}$ & $0.56 \mathrm{~b}$ & $0.25 \mathrm{a}$ & $0.30 \mathrm{a}$ \\
\hline Total S ( $\left.\mathrm{g} \mathrm{kg}^{-1}\right)$ & $0.55 \mathrm{c}$ & $0.42 \mathrm{~b}$ & $0.38 \mathrm{ab}$ & $0.31 \mathrm{a}$ \\
\hline Organic $\mathrm{P}\left(\mathrm{g} \mathrm{kg}^{-1}\right)$ & $0.42 \mathrm{c}$ & $0.36 \mathrm{c}$ & $0.10 \mathrm{a}$ & $0.22 \mathrm{~b}$ \\
\hline $\begin{array}{l}\text { Alkali-hydrolyzed } \\
\mathrm{N}\left(\mathrm{mg} \mathrm{kg}^{-1}\right)\end{array}$ & $126.57 \mathrm{~d}$ & $42.62 \mathrm{c}$ & $26.48 \mathrm{a}$ & $37.45 \mathrm{~b}$ \\
\hline $\begin{array}{l}\text { Available P } \\
\left(\mathrm{mg} \mathrm{kg}^{-1}\right)\end{array}$ & $102.10 \mathrm{c}$ & $29.71 \mathrm{~b}$ & $11.00 \mathrm{a}$ & $10.37 \mathrm{a}$ \\
\hline $\begin{array}{l}\text { Available } \mathrm{S} \\
\left(\mathrm{mg} \mathrm{kg}^{-1}\right)\end{array}$ & $23.10 \mathrm{c}$ & $10.74 \mathrm{ab}$ & $11.07 \mathrm{~b}$ & $9.50 \mathrm{a}$ \\
\hline Clay (\%) & $34.6 \mathrm{c}$ & $18.6 \mathrm{a}$ & $20.2 b$ & $18.9 \mathrm{a}$ \\
\hline Silt (\%) & $51.5 \mathrm{~b}$ & $67.8 \mathrm{c}$ & $50.8 \mathrm{~b}$ & $35.7 \mathrm{a}$ \\
\hline Sand $(\%)$ & $13.9 \mathrm{a}$ & $27.9 \mathrm{~b}$ & $29.0 \mathrm{~b}$ & $45.4 \mathrm{c}$ \\
\hline
\end{tabular}

Different letters in columns indicate significant differences between treatments $(\mathrm{p}<0.05)$

Soil enzyme activities and kinetic parameters measurement

Enzyme substrates (urea, sodium pnitrophenyl phosphate, and potassium pnitrophenyl sulfate) were purchased from Sigma-Aldrich Inc., Seebio Biotech Inc., and J\&K China Chemical Ltd., respectively.

Soil urease (EC $\left.3.5 .1 .5,37^{\circ} \mathrm{C}\right)$ activity was assayed by the method of Tabatabai and Bremner (1994). 6.0g soil samples were reacted with urea at $37^{\circ} \mathrm{C}$ for $5 \mathrm{~h}$, and the amount of residual urea was determined by using diacetyl monoximeantipyrine in $\mathrm{KCl}$-acetic phenyl mercury extract. Soil phosphatases (orthophosphoric monoester phosphorhydrolases, EC 3.1.3.2, pH 6.5, and EC 3.3.3.1, $\mathrm{pH}$ 11) activities and arylsulphatase (EC 3.1.6.1, $\mathrm{pH}$ 5.8) activity were also assayed by the method of Tabatabai and Bremner (1994). About $1 \mathrm{~g}$ soil sample was reacted with sodium $p$-nitrophenyl phosphate or potassium $p$ nitrophenyl sulfate at $37^{\circ} \mathrm{C}$ for $1 \mathrm{~h}$, and the released p-nitrophenol was measured 
by colorimetry. All the measurements were performed at optimal $\mathrm{pH}$. The same procedures in enzyme activities measurements were followed for the controls, but the substrates were added to the soil samples after incubation and prior to the analysis of residual substrate or reaction product.

The kinetic parameters $V_{\max }$ (maximum enzyme velocity) and $K_{m}$ (substrate affinity constant) were calculated by using Michaelis-Menten equation. Seven concentrations $(3,5,7,10,15,20$, and 30 mmol L $\left.{ }^{-1}\right)$ of urea solution, six $(0.2,0.5$, $1,5,15$, and $50 \mathrm{mmol} \mathrm{L}^{-1}$ ) of sodium $p$ nitrophenyl phosphate, and seven $(0.5,1$, $5,10,15,25$, and $50 \mathrm{mmol} \mathrm{L}^{-1}$ ) of potassium $p$-nitrophenyl sulfate were used as the substrates of soil urease, phosphatase, and arylsulphatase, respectively. Each determination was also triplicated. The parameters were calculated by nonlinear regression of the statistical software origin 8.0.

\section{Statistical analysis}

The experiments followed a completely randomized design. All data were presented as the means of triplicate analyses of triplicate samples. All the values reported were expressed as per $\mathrm{g}$ oven-dried soil $\left(105^{\circ} \mathrm{C}\right)$. The effects of soil moisture content were analyzed by variance analysis (one - way ANOVA), Least significant difference at $\mathrm{p}=0.05$. (LSD) and Pearson correlation coefficients (r) were calculated by using SPSS 11.0.

\section{RESULTS}

Effects of soil moisture regime on soil hydrolases $K_{m}$ and $V_{\max }$ Figure 1 showed that the $1 / K_{m}$ and $V_{\max }$ values of test soil enzymes varied with soil moisture content and soil type. The substrate affinity $\left(1 / K_{m}\right)$ of soil urease increased with soil moisture content, with the peak at $30 \%$ field capacity in albic, brown, and cinnamon soils and at $20 \%$ field capacity in black soil. Soil phosphatase had the highest $1 / K_{m}$ at $10 \%$ filed capacity in albic soil, at $30 \%$ field capacity in brown and cinnamon soils, and at $20 \%$ and $30 \%$ field capacity in blank soil; while soil arylsulphatase had the highest $1 / K_{m}$ value at $10 \%$ field capacity in albic soil, at $20 \%$ field capacity in blank soil, and at 30\% field capacity in brown and cinnamon soils.

The $V_{\max }$ of soil urease was the highest at $10 \%$ field capacity in black, albic, and brown soils and at $20 \%$ field capacity in cinnamon soil. Soil phosphatase had the highest $V_{\max }$ at $30 \%$ field capacity in blank and albic soils but nearly the same at all test field capacities in brown and cinnamon soils, while that of arylsulphatase was the highest at 30\% field capacity in black and albic soils and at $10 \%$ field capacity in brown and cinnamon soils.

The $1 / K_{m}$ and $V_{\max }$ had larger variations at $20 \%-30 \%$ field capacity than at $10 \%-20 \%$ field capacity, suggesting their different responses to different soil moisture regimes.

\section{Effects of soil moisture regime on soil hydrolases catalytic efficiency $\left(V_{\max } / K_{m}\right)$}

It's shown in Table 2 that soil urease had higher $V_{\max } / K_{m}$ at $20 \%$ field capacity in black soil, at $10 \%$ and $30 \%$ field capacity in albic and brown soils and at $20 \%$ and $30 \%$ field capacity in cinnamon soil, soil phosphatase had higher $V_{\max } / K_{m}$ at $20 \%$ and $30 \%$ field capacity in black and cinnamon soils, at $10 \%$ and $30 \%$ field capacity in albic soil and at $30 \%$ field capacity in brown soil, and soil 

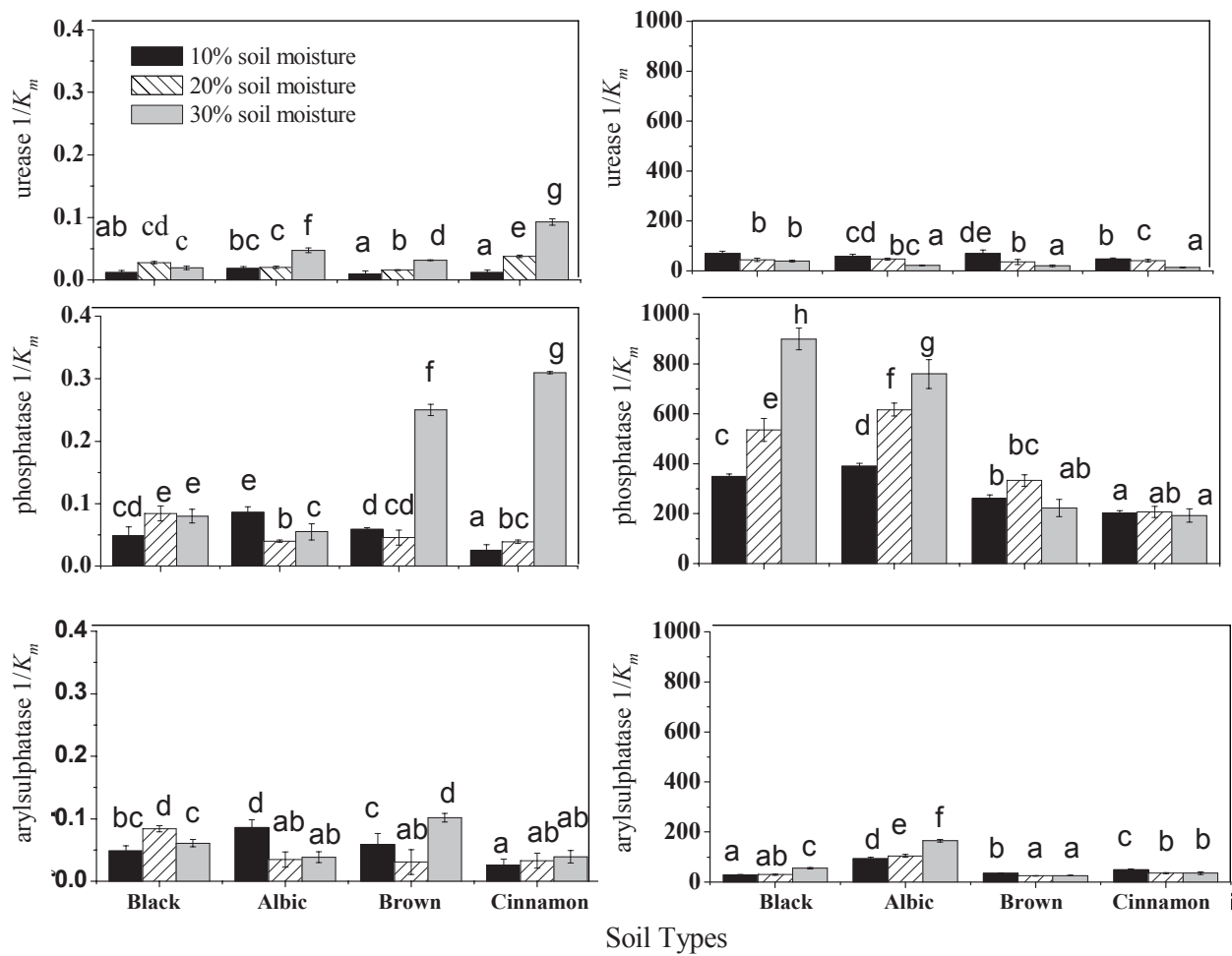

Figure 1: $K_{m}$ and $V_{\max }$ values of soil urease, phosphatase, and arylsulphatase under different soil moisture conditions. $\left(K_{m}=\mathrm{mmol} \mathrm{L}^{-1} ; V_{\max }=\mu \mathrm{g} \mathrm{g}^{-1}\right.$ soil h$\left.^{-1}\right)$. Different letters indicate significant differences between treatments $(\mathrm{p}<0.05)$

arylsulphatase had higher $V_{\max } / K_{m}$ at $20 \%$ and $30 \%$ field capacity in black soil and at $10 \%$ and $30 \%$ field capacity in albic and brown soils, but the same $V_{\max } / K_{m}$ at $10 \%$, $20 \%$ and $30 \%$ field capacity in cinnamon soil.

\section{DISCUSSION}

In general, soil enzyme-substrate affinity $\left(1 / K_{m}\right)$, similar to free enzyme (Balkan and Ertan, 2007), is increased with increasing soil moisture content because of the enhanced dissolution and translocation of the substrates (Zhou, 1987). However, increasing soil moisture content could decrease substrate concentration, resulting in the decrease of $1 / K_{m}$. The different variation patterns of the $1 / K_{m}$ in test soils depended partly on how the soil moisture regime affected the distribution of the enzymes and their substrates (Boyd and Mortland, 1990).

Some studies suggested that soil enzyme activity was strongly affected by soil moisture regime (Skujins and Mclaren, 1969; Delaune and Patrick, 1970; Kramer and Green, 2000; Wang and Lu, 2006; Yavitt, 2004). There was a 
significant correlation between soil phosphatase activity and moisture content (Harrison, 1983; Speir and Coling, 1991; Subhani, et al., 2000), and the rank correlation in the study of Bergstrom et al. (1998) indicated the significant relationships between soil enzyme activities (urease, phosphatase, and arylsulphatase etc.) and moisture content, which was further confirmed by this study.

The catalytic efficiency of soil enzymes $V_{\max } / K_{m}$ (Gianfreda et al., 1995) was highly affected by soil organic matter content and soil texture (Bery et al., 1978; Zaman et al., 1999; Garcia et al., 1993). Higher $V_{\max } / K_{m}$ of test soil enzymes was found in the test soils containing more organic matter and having better texture. In the meantime, less variation of $V_{\max } / K_{m}$ was observed in these soils under effects of different soil moisture condition because of the buffering effects of higher organic matter and clay particle contents.

\section{CONCLUSIONS}

The catalytic potential of test hydrolases in the main agricultural soils of Northeast China was affected by the soil moisture regime in some degree, depending on the organic matter content and texture of these soils. The soils with higher organic matter and clay particle contents had less variation of their catalytic potential under different soil moisture conditions. To control soil moisture condition could be a feasible way in regulating the biochemical transformation processes of soil nutrients catalyzed by soil hydrolases.

\section{ACKNOWLEDGEMENTS}

This study is supported by the National Basic Research Program (973 Program) (2007CB109307) and the Technology Supporting Program (2006BAD10B01) of China. We thank Professor Zhou LK for his critical review of our manuscript, and the staffs of Department Soil and Plant Nutrition, Institute of Applied Ecology under Chinese Academy of Sciences for their academic and technical assistance.

\section{REFERENCES}

Amador, J.A., Glucksman, A.M., Lyons, J.B., Gorres, J.H. 1997. Spatial distribution of soil phosphatase activity within a riparian forest. Soil Science. 162, 808-825.

Asmar, F., Eiland, F., Nielsen, N.E. 1994. Effect of extracellular-enzyme activities on solubilization rate of soil organic nitrogen. Biology and Fertility of Soils. 17, 32-38.

Balkan, B., Ertan, F. 2007. Production of aAmylase from P. chrysogenum under Solid-State Fermentation by Using Some Agricultural byProducts. Food Technology and Biotechnology. 45 (4), 439-442.

Bergstrom, D.W., Monreal, C.M., Millette, J. A., King, D.J. 1998. Spatial dependence of soil enzyme activities along a slope. Soil Science Society of America Journal. 62, 1302-308.

Bery, Viraj., Goswami, K.P., Brar, S.S. 1978. Urease activity and its Michaelis constant for soil systems. Plant and Soil. 4, 105-115.

Boyd, S.A., Mortland, M.M. 1990. Enzyme interactions with clays and clay-organic matter complexes. In Soil Biochemistry, Vol.6. Bollag J. M. and Stotzky G, Eds. Marcel Dekker, New York, pp 1-28. 
Burns, R.G. 1978. Soil Enzymes. 8-250 p. New York: Academic Press.

Delaune, R.D., Whpatrick, J.R. 1970. Urea conversion to ammonia in waterlogged soils. Soil Science Society of America Proceeding. 34(4), 603-607.

Dick, W.A., Tabatabai, M.A. 1993. Significance and potential uses of soil enzymes. In: Metting, F.B. Jr (Ed.), Soil Microbial Ecology. Marcel Decker Inc, New Yourk, USA.

Engasser, J.M., Horvath, C. 1976. Diffusion and kinetics with immobilized enzymes. In Applied Biochemistry and Bioengineering, Volume 1 Immobilised enzyme principles. Ed. Wingard L.B., Katchalski-Katzir E. and Goldstein L., pp 127-220.

Fox, R.L., Hue, N.V., Parra, A.J. 1987. A Turbidimetric method for determining phosphateextractable sulfates in tropical soils. Communication in Soil Science and Plant Analysis. 18(4), 343-357.

García, C., Hernández, T., Roldan, A., Martin, A. 2002. Effect of plant decline on chemical microbiological parameters under Mediterranean climate. Soil Biology and Biochemistry. 34, 635642.

Gianfreda, L., De Cristofaro, A., Rao, M.A., Violante, A. 1995. Kinetic behavior of synthetic organo-and-organo-mineral-urease complexes. Soil Science Society of America Journal. 59, 811-815.

Harrison, A.F. 1983. Relationship between intensity of phosphatase activity and physico chemical properties in woodland soils. Soil Biology and Biochemistry. 15, 93-99.

Kramer, S., Green, D.M. 2000. Acid and alkaline phosphatase dynamics and their relationship to soil microclimate in semiarid woodland. Soil Biology and Biochemistry. 32, $179-188$.
Kuo, S. 1996. Phosphorus. In: Sparks, D. L., et al. (Eds.), Methods of soil Analysis, Part 3, Chemical Methods. SSSA Book series No. 5. Soil Science of America, Madison, WI, pp. 869-919.

Ladd, J. N. 1985. Soil enzymes. In: Soil organic matter and biological activity. Vaughan D and Malcom RE. Eds. Nijhoff, Dordrecht, pp. 175222.

Lu, R. K (Ed). 2000. Methods of soil and agrochemistry analysis. Chinese Agricultural Science and Technology Press, Beijing (in Chinese).

Matejovic, I. 1995. Total nitrogen in plant material determined by means of dry combustion: a possible alternative to determination by Kjeldahl digestion. Communication in Soil Science and Plant Analysis. 26, 2217-2229.

Ross, D.J. 1987. Soil microbial biomass estimated by the fumigation-incubation procedure: Seasonal fluctuation and influence of soil moisture content. Soil Biology and Biochemistry. 19, 397-404.

Sardans, J., Penuelas, J. 2005. Drought decreases soil enzyme activity in a Mediterranean Quercus ilex L. forest. Soil Biology and Biochemistry. 37, 455-461.

Speir, T.W., Cowling, J.C. 1991. Phosphatase activities of pasture plants and soils: relationship with plant productivity and soil $\mathrm{P}$ fertility indices. Biology and Fertility of Soils. 12, 189-94.

Subhani, A., Liao, M., Huang, C.G., Xie, Z.M. 2000. Effects of some management practices on electron transport system (ETS) activity in paddy soil. Pedosphere. 10(3):257-264.

Tabatabai, M.A. 1994. Soil enzymes. In: Weaver RW, Angle JR, Bottomley PS (Eds). Methods of soil analysis: microbiological and biochemical properties. Part 2. SSSA Book Ser. 5. Soil Sci. Soc. Am. Madison, WI. 1994. pp. 775 $-833$. 
Tabatabai, M.A., Bremner, J.M. 1971. Michaelis constant of soil enzymes. Soil Biology Biochemistry. 3, 317 - 323.

Tabatabai, M.A., Bremner, J.M. 1972. Assay of urea activity in soils. Soil Biology Biochemistry. 4, 479-487.

Wang, X. C., Lu, Q. 2006. Effect of waterlogged and aerobic incubation on enzyme activities in paddy soil. Pedosphere. 16(4), 532-539.

Yavitt, J. B., Wright, S. J., Wieder, R. K. 2004. Seasonal drought and dry-season irrigation influence leaf-litter nutrients and soil enzymes in a moist, lowland forest. Panama Austral Ecology. $29,177-188$.
Zaman, M., Di, H.J., Cameron, K.C. 1999. A field study of gross of $\mathrm{N}$ mineralization and nitrification and their relationships to microbial biomass and enzyme activities in soils treated with dairy effluent an ammonium fertilizer. Soil Use Manage. 5, 188-194.

Zhou, L.K. 1987. Soil Enzymology. Beijing: Science Press (in Chinese). 